\title{
高松塚古墳壁画の黒色顔料の微細構造
}

\author{
北田正 弘 ${ }^{1, *} \quad$ 高 妻 洋成 ${ }^{1} \quad$ 肥塚隆 保 $^{1} \quad$ 建 石 $\quad$ 徹 $^{2}$ \\ 1奈良文化財研究所埋蔵文化財センター \\ 文化庁文化財部
}

J. Japan Inst. Met. Mater. Vol. 79, No. 2 (2015), pp. 71-75

(C) 2015 The Japan Institute of Metals and Materials

\section{Microstructure of Black Pigment Painted on the Takamatsuzuka Tumulas Wall}

\author{
Masahiro Kitada $^{1, *}$, Yohsei Kohzuma ${ }^{1}$, Takayasu Koezuka ${ }^{1}$ and Toru Tateishi ${ }^{2}$ \\ ${ }^{1}$ Center for Archaeological Operations, Nara National Research Institute for Cultural Properties, Nara 630-8577 \\ ${ }^{2}$ Cultural Properties Department, Agency for Cultural Affairs, Tokyo 110-8914
}

The mural of the Takamatsuzuka tumulus in Asuka, Nara prefecture, was painted in the 7-8th centuries. Red, green, blue, yellow, and black pigments are used in the mural. The microstructure of one of them, the red pigment, was described in the previous paper. In this study, the black pigment observed within the red pigment area has been investigated. An optical microscope, a scanning electron microscope, and a transmission electron microscope are utilized to examine the microstructure. Among the black particles, two different $\mathrm{Fe}$ compounds are observed. One is magnetite $\left(\mathrm{Fe}_{3} \mathrm{O}_{4}\right)$ comprising small amounts of Ti, $\mathrm{Al}$, and $\mathrm{Mg}$, and the other is ilmenite $\left(\mathrm{FeTiO}_{3}\right)$ containing a small amount of $\mathrm{Mg}$. In addition to the above compounds, an oxide particle containing $\mathrm{Zr}$ is also observed. [doi:10.2320/jinstmet.J2014051]

(Received October 17, 2014; Accepted November 28, 2014; Published February 1, 2015)

Keywords: Takamatsuzuka tumulus, mural, black pigment, magnetite, ilmenite, zirconium

\section{1. 緒言}

高松塚古墳の壁画は赤色, 緑色, 青色, 黄色抢よび黒色等 の顔料で彩色されており，他に金䈃が使われている。これら の顔料については，その成分を蛍光 X 線等で分析し1)，その 結果から使用している顔料を推定している.しかし, 顔料化 合物の直接的な分析と解析はなされていなかった．著者らは 前報2)で述べたように, 赤色の顔料について初めて分析と解 析を行い, 辰砂 (cinnabar, HgS, 水銀朱)であることを明か にした.この試料を光学顕微鏡で観察すると, 辰砂に混じっ て黒色の粒子が存在していた. 自然界の $\mathrm{HgS}$ 鉱物には赤色 の辰砂と黒色の黒辰砂が存在し, 使われている顔料中の黒色 粒子が黒辰砂であるのか, あるいは異なる物質であるのかを 明らかにするため，黒色の粒子について詳細を調べた。

本報では, 高松塚古墳壁画試料の表面に付着していた彩色 顔料層に存在する黒色粒子の分析結果と付随して得られた物 質粒子について述べる.

\section{2. 実 験 方 法}

用いた試料は前報 2 と同じもので, 主に赤色顔料が付着し た漆喰片である. 試料の観察には, 光学顕微鏡, 走査電子顕

\footnotetext{
* 東京藝術大学名誉教授 (Professor Emeritus, Tokyo University of the Arts)
}

微鏡および透過電子顕微鏡 (Hitachi HD-2700)を用いた. 試 料は絶縁体なので，試料表面のチャージアップを低減できる 低真空走查電子顕微鏡 (Hitachi SU-3500)を用いた。組成は EDS(Electron Dispersive X-ray Spectroscopy，EDX とも略 される)で分析した。透過電子顕微鏡観察用の薄膜試料は FIB (Focused Ion Beam) 装置で加工した. FIB 加工にあたっ ては, 付着粒子を安定にするため, 市販の $\alpha$-シアノアクリ アート系接着剤を浸透させて表面部を補強した.

\section{3. 実 験 結 果}

\section{1 光学顕微鏡観察}

漆喰基盤上の顔料粒子が付着している部分の光学顕微鏡像 をFig. 1 に示す．表面の凹凸が激しいので焦点は一部分し か合っていないが，白色の漆喰基板上に赤色顔料領域があ り，その中に黒色の粒子が存在する．黑色粒子は赤色粒子と 混合されたような状態で分布している。この顔料部の X 線 回折を試みたが, 前報2)で述べたように, 基板(地)の漆喰成 分である $\mathrm{CaCO}_{3}$ 以外の物質は検出できなかった.

\section{2 走査電子顕微鏡観察}

顔料の観察領域において, 辰砂の成分である $\mathrm{Hg}$ と $\mathrm{S}$ 以外 に検出された元素は $\mathrm{C}, \mathrm{O}, \mathrm{Mg}, \mathrm{Al}, \mathrm{Si}, \mathrm{Ca}$ ，および $\mathrm{Fe}$ であ り2), これらの元素を含む酸化物の中で黒色化合物として考 えられるのは, 黒辰砂および自然界で容易に見出される Fe を含む磁鉄鉱や砂鉄などである.この可能性を探るために, 
光学顕微鏡で黒色粒子が観察された領域の元素の分布を調べ た.この領域の SEM(反射電子)像と $\mathrm{Fe}$ 抢よび $\mathrm{Ti}$ の元素分 布像(元素マップ)をFig. 2 に示す．ここで，元素マップに おける像の明るさは元素の存在領域を明確にするためにそれ ぞれの元素について調整しており，元素間の濃度の高低を表 しているものではない. Fig. 2 で示した観察領域の EDS 分 析では，C， O, S, Mg, Al, Si, Ca, Ti, Fe, Hg が検出された。C には大気から吸着した炭化水素の $\mathrm{C}$ も含まれていると思わ れる. SEM 像の明るい領域には $\mathrm{Hg}$ と S が分布し, 前報 2 で述べたように，ここは $\mathrm{HgS}$ 粒子が存在する領域である. 暗い領域の大部分には $\mathrm{Ca}, \mathrm{C}$ および $\mathrm{O}$ の多くが分布してい るので, 漆喰の成分の $\mathrm{CaCO}_{3}$ が存在領域である.

元素マップで示したように, Fe が検出された部分では, 多くの粒子で Fe とともに Ti が検出されたが，Ti が検出さ れない粒子もある. Fe と $\mathrm{Ti}$ の存在する領域には $\mathrm{O}$ も存在 し， $\mathrm{Fe}$ などを含む酸化物である． Fe の天然化合物として赤 鉄鉱 $\left(\mathrm{Fe}_{2} \mathrm{O}_{3}\right)$ あるいは磁鉄鉱 (理想化学組成は $\mathrm{Fe}_{3} \mathrm{O}_{4}$ )の可能 性がある. $\mathrm{Fe}_{2} \mathrm{O}_{3}$ は赤茶色なので光学顕微鏡で観察された黒 い粒子とは色が異なり，黒い粒子は $\mathrm{Fe}_{2} \mathrm{O}_{3}$ ではない. $\mathrm{Fe}_{3} \mathrm{O}_{4}$

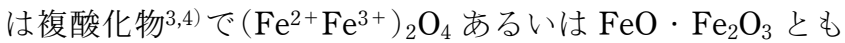
書かれ，2 価の Fe の寄与で黒色となる。一方， Fe と Ti が 共存する部分では，イルメナイト(理想化学組成は $\mathrm{FeTiO}_{3}$ ) 系酸化物が考えられ5)，これも 2 価の $\mathrm{Fe}$ の寄与で黒色であ る. 光学顕微鏡で観察された黒色粒子が $\mathrm{Fe}_{3} \mathrm{O}_{4}$ あるいはイ

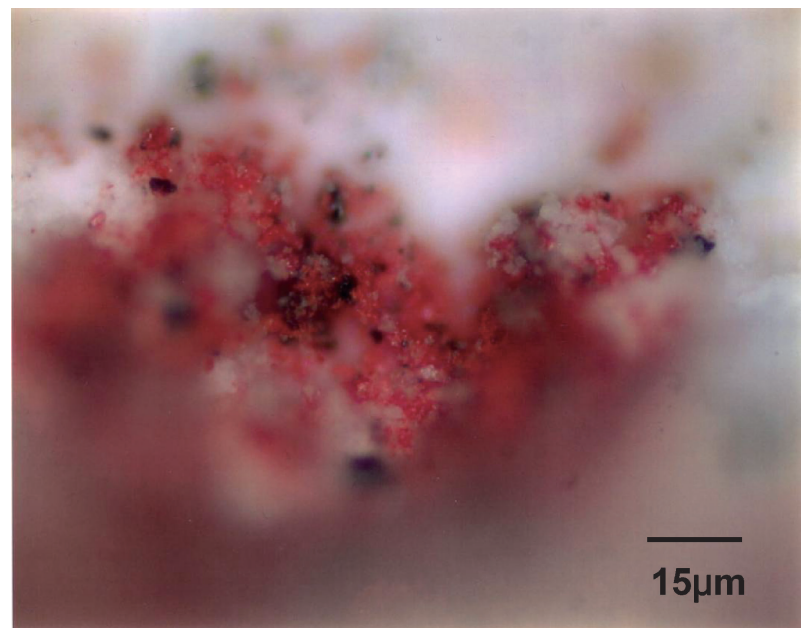

Fig. 1 Optical micrograph of red and black pigments painted on the stucco base.
ルメナイト系酸化物であれば，鉱物として砂鉄の可能性があ る.

イルメナイト系酸化物が存在すると考えられる Fig. 2 で 示した Fe と Ti が共存する部分 (Fig. 2 の SEM 像および Fe マップの矢印部)の拡大した SEM 像を Fig. 3 に示す。矢印 で示した粒子に $\mathrm{Fe} ， \mathrm{Ti}$ ，および $\mathrm{O}$ が含まれ，長手方向の長 さは約 $9 \mu \mathrm{m}$ で，表面には微粒子が付着している. 図中に示 すように，周囲には $\mathrm{HgS}$ 抢よび $\mathrm{CaCO}_{3}$ 粒子が存在する．矢 印で示した粒子の EDS 像を Fig. 4 に示す. 表面に付着して いる物質や周囲の物質の信号も含まれていると見られるが， 金属元素として Fe と Ti のピークが明瞭に存在する. EDS で得られた $\mathrm{Fe}, \mathrm{Ti}$ ，および $\mathrm{O}$ の原子数比からは，大略 $\mathrm{Fe}_{1.2} \mathrm{TiO}_{3.3}$ となり, $\mathrm{Ti}$ が若干少ないが上述のイルメナイト に近い組成である.

このほかに, Fig. 5 の矢印で示す小さな粒子からは Fig. 6 の EDS 像で示すように $\mathrm{Zr}$ が検出された．Ca は周囲あるい は表面に付着している $\mathrm{CaCO}_{3}$ に由来するものと考えられる. Ti と Zr は鉱物中で共存することもあるが，EDSで得られ た Ti の量は非常に少なく, $\mathrm{Fe}$ も非常に少ないので，砂鉄系 の鉱物ではない，測定数が少なく，詳しい組成は得られなか ったが，EDS で検出された $\mathrm{Zr} / \mathrm{Si}$ 比は 0.83 であった， $\mathrm{Zr}$ の 珪酸塩としてはジルコン (理想化学組成は $\left.\mathrm{ZrSiO}_{4}\right)$ がある. $\mathrm{Ca}$ も検出されているので, $\mathrm{Ca}$ と $\mathrm{Zr}$ を含むケイ酸塩鉱物の 可能性もある. $\mathrm{Zr}$ を含む鉱物粒子の観察例は少ないので他 の鉱物に付随するものと考えられるが, 将来, 使用された顔 料等の産地の同定に使える可能性がある.

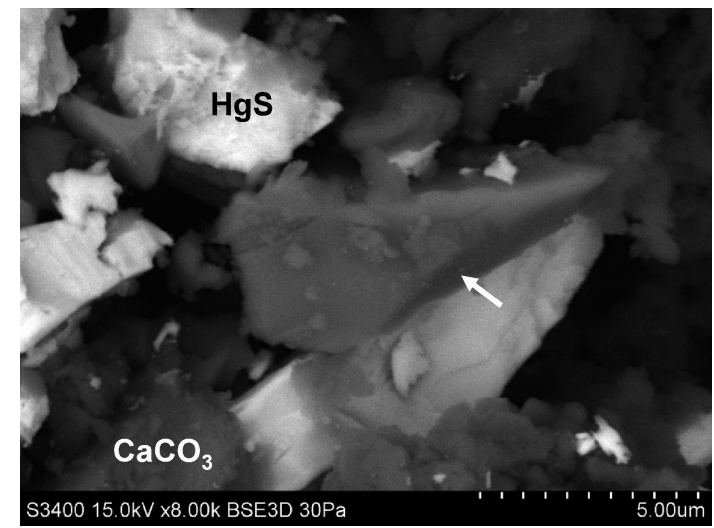

Fig. 3 SEM image of the grain containing $\mathrm{Fe}$, Ti, and $\mathrm{O}$ indicated by the arrow shown in Fig. 2.
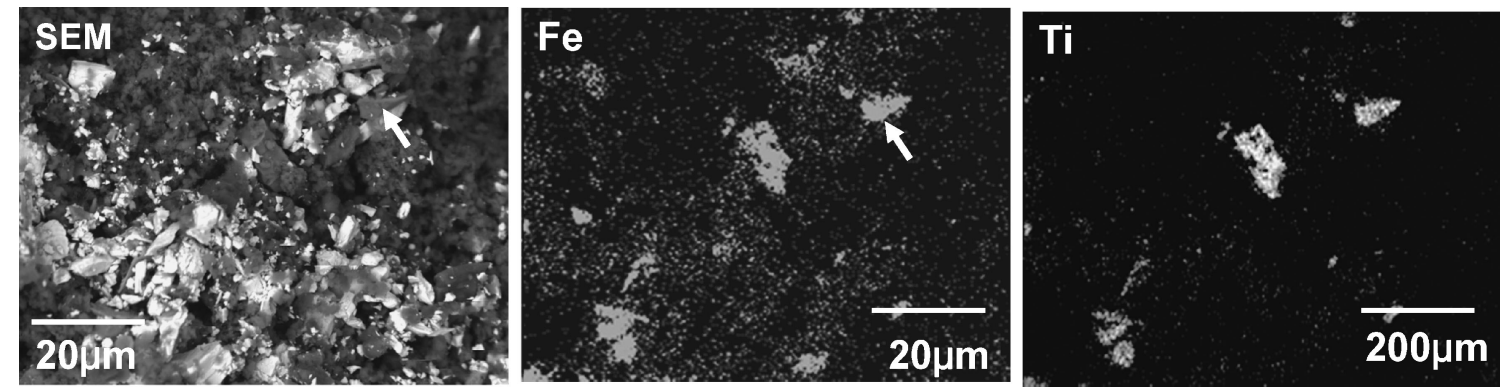

Fig. 2 Scanning electron micrograph (SEM) and elemental maps of Fe and Ti. Arrows indicate Fe-Ti-O compound. 


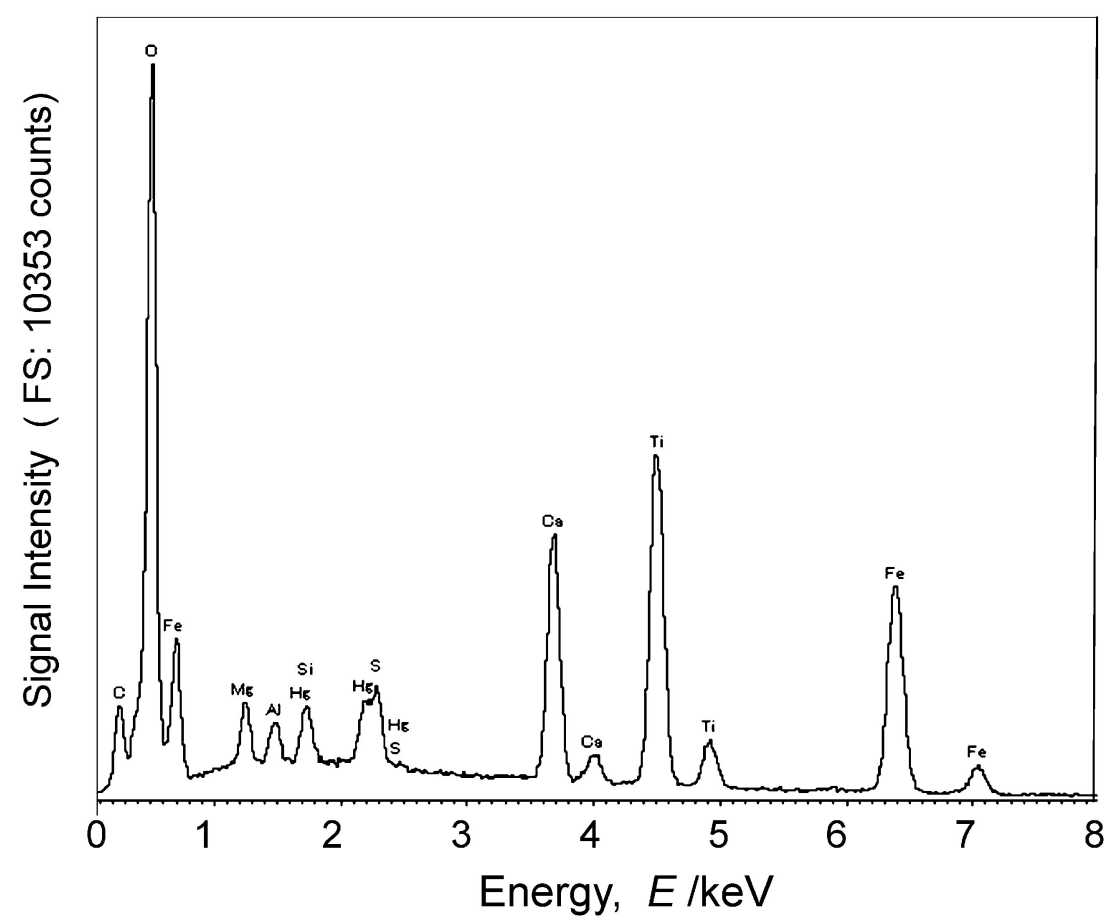

Fig. 4 EDS pattern of the grains indicated by the arrow shown in Fig. 3.

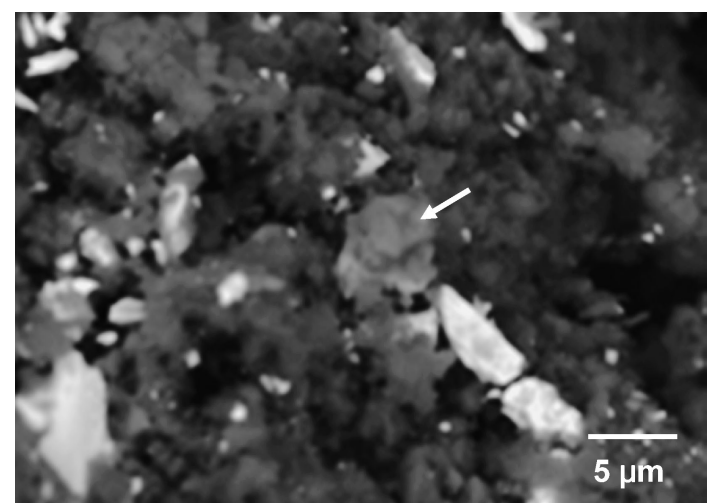

Fig. 5 SEM image of the grains containing $\mathrm{Zr}$ indicated by the arrow.

\section{3 透過電子顕微鏡観察}

走查電子顕微鏡による観察と分析で顔料等の大略は明かに なったが，SEM 観察では試料表面の污れも多いため，さら なる確認のために，透過電子顕微鏡で観察した．Fig. 7 は FIB で薄膜化した黒い粒子の TEM 像と，主な元素マップで ある. 元素マップ像の明るさは元素の存在領域を明確にする ためそれぞれで明るさを調整しており, 元素間の濃度の高低 を示すものではない. TEM 像では, 挿入記号 A と B で示 すように，ふたつの粒子が観察される。これらのコントラス トの差は内部欠陥抢よび結晶方位の差などの影響とみられ る. 元素マップから, 粒子 $\mathrm{A}$ は $\mathrm{Fe}$ と $\mathrm{Ti}$ が多く存在する酸 化物であるが，粒子 B では Ti の濃度が相対的に少ない。 ま た，ぞちらの粒子からも $\mathrm{Al}$ と $\mathrm{Mg}$ が検出された. Fig. 8 は 粒子 A と B の EDS 像で, Fig. 4 で示した EDS 像に比較し て，Caなどの信号は殆どない。これは，SEM 観察でみられ
た粒子表面の付着物などの影響が FIB による薄膜化で除か れたためで, 粒子の本来の成分に近いものと及なされる. 粒 子 $\mathrm{A}$ では, 明かに $\mathrm{Fe}$ と多量の $\mathrm{Ti}$ が存在し, B では $\mathrm{Ti}$ が少 なく, 両者の組成は異なる. $\mathrm{Al}$ と $\mathrm{Mg}$ の含有量にも差がみ られる。

チタンを含む酸化鉄系化合物には代表的な ilmenites $\left(\mathrm{FeTiO}_{3}\right)$, ulvospinel $\left(\mathrm{Fe}_{2} \mathrm{TiO}_{4}\right)$, および $\mathrm{Fe}_{2} \mathrm{TiO}_{5}$ などがあ り, $\mathrm{Mg}$ を含むものは $\mathrm{FeMg}_{0.5} \mathrm{Ti}_{1.5} \mathrm{O}_{5}$ などがある3,6).また, ilmenite 構造の金属元素が $\mathrm{Al}$ になると $\alpha \mathrm{Al}_{2} \mathrm{O}_{3}$ のコランダム 構造と同じになるので, $\mathrm{Al}$ も $\mathrm{Fe}$ あるいは $\mathrm{Ti}$ に置換して固 溶する. Fig. 7 で示した粒子 A の電子線回折図形を Fig. 9 (a)に示す。これを解析した結果, ilmeniteである $\mathrm{FeTiO}_{3}$ 7) に一致した. また, Fig. 9(b)で示す粒子 B の電子線回折図

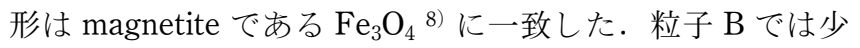
量の Ti が含まれている.フェライト磁石でよく知られてい るように, 前述のマグネタイト $\left(\mathrm{Fe}^{2+}\right)\left(\mathrm{Fe}^{2+} \mathrm{Fe}^{3+}\right) \mathrm{O}_{4}$ は $\mathrm{Fe}^{2+}$ 抢よび $\mathrm{Fe}^{3+}$ に種々の元素が置換する. EDS で検出さ れた $\mathrm{Mg}$ 打よび $\mathrm{Mn}$ などは $\mathrm{Fe}^{2+}$ に置換型で固溶し, $\mathrm{Fe}^{3+}$ には $\mathrm{Al}, \mathrm{Cr}$ 抢よび $\mathrm{Ti}$ などが置換型で固溶する ${ }^{3,4}$. 検出さ れた $\mathrm{Mg}$ 抢よび $\mathrm{Al}$ はこのような形で固溶しているとみられ る. 以上の観察と解析結果から, 光学顕微鏡で観察された黒 い粒子は砂鉄と考えられる. 砂鉄粒子の組成は多様である が9), この観察結果では 2 種の化合物が検出された.

これらの結晶中には格子欠陥が観察され, Fig. 7 で示した A の ilmenite 中の一例を Fig. 10 に示す. 上部が結晶の表面 で，複数の転位は表面から結晶内部に $[1 \overline{2} 0]$ 方向と平行な方 向に移動した状態のすべり転位で, 結晶成長のときに導入さ れる転位とは形態が異なる. また, この種の化合物のモース 硬度は 5〜6で，容易に塑性変形する軟らかさではない。し たがって,これらは高い応力によって表面から導入された転 


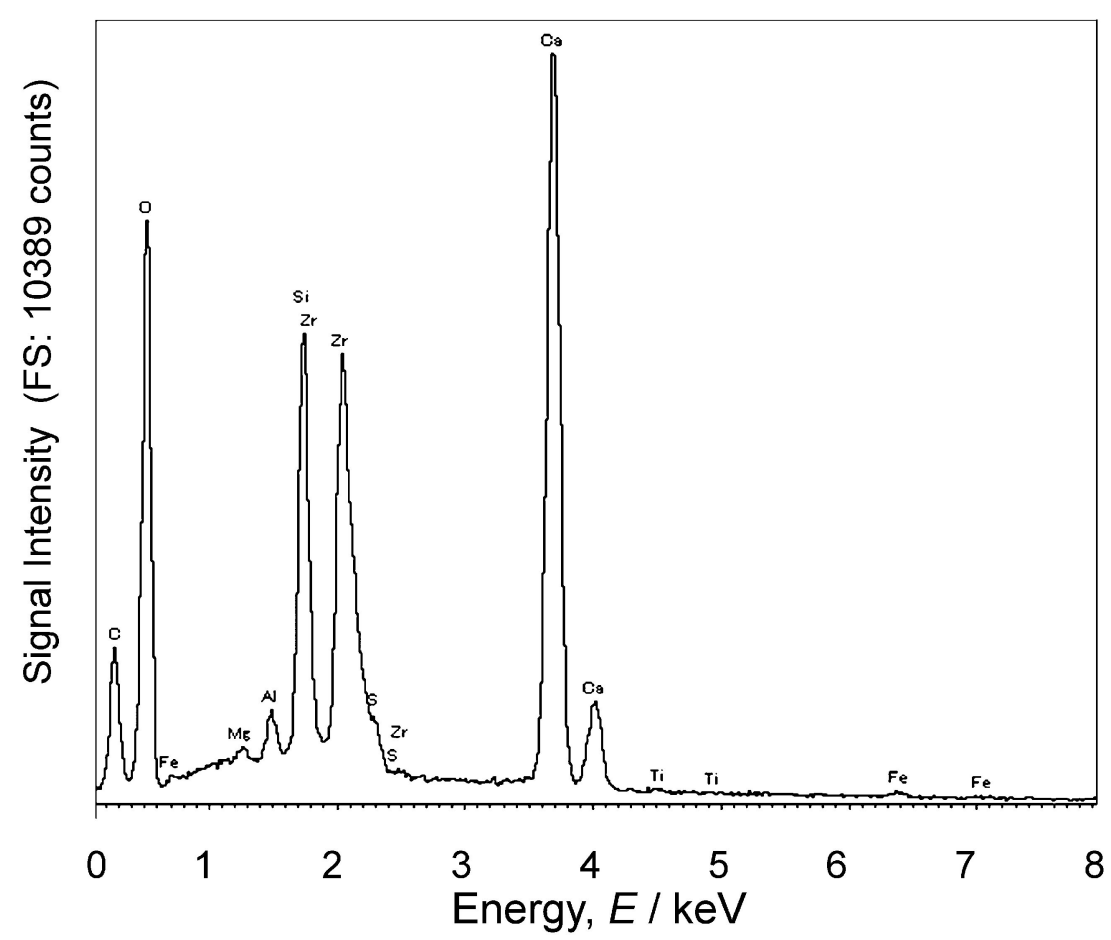

Fig. 6 EDS pattern of the grain indicated by the arrow shown in Fig. 5.
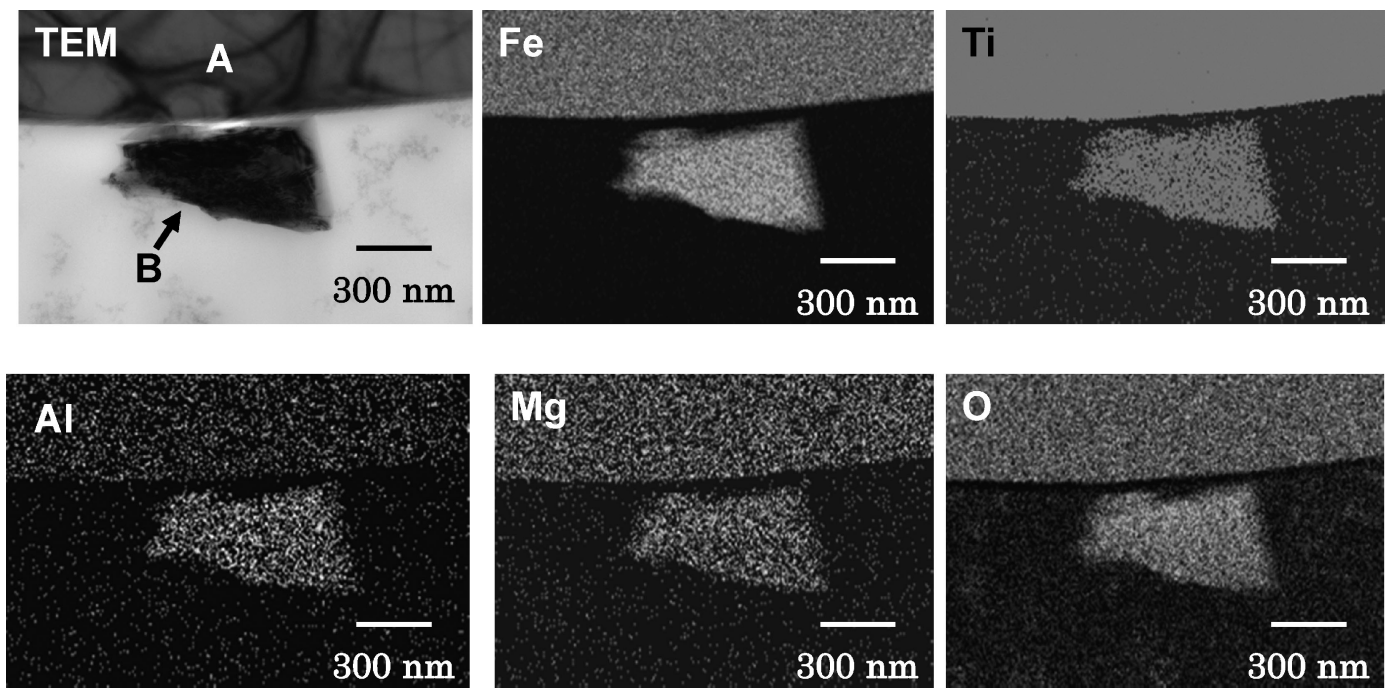

Fig. 7 Transmission electron micrograph (TEM) and elemental maps of black grains.

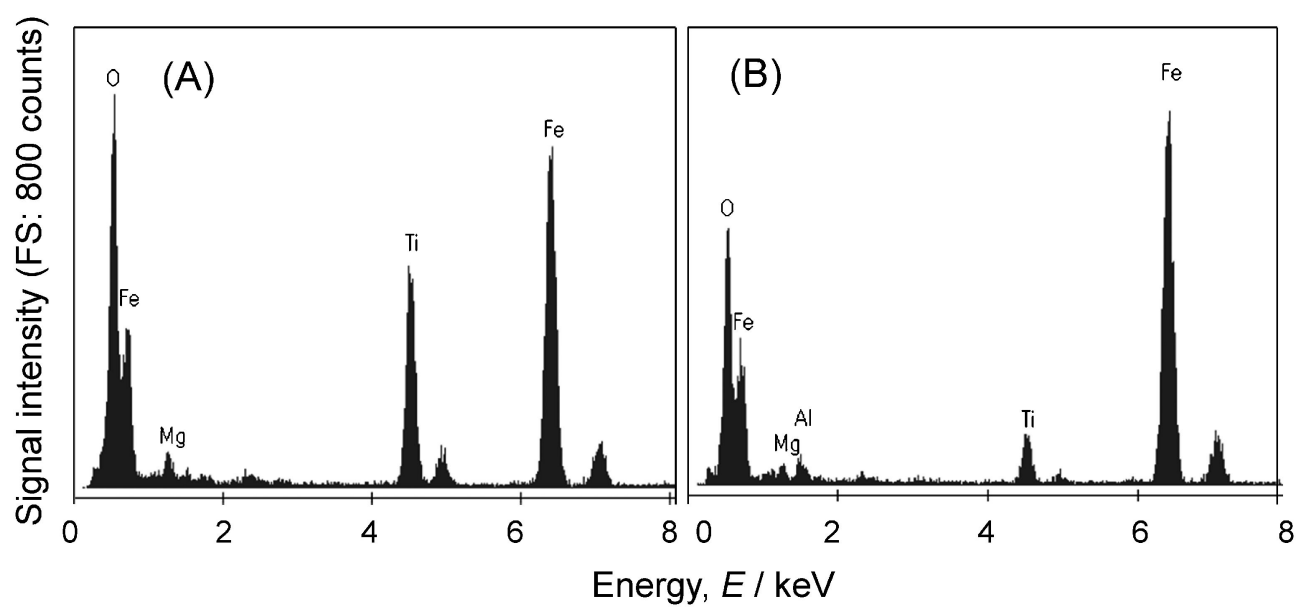

Fig. 8 EDS patterns of grains A and B indicated in Fig. 7. 

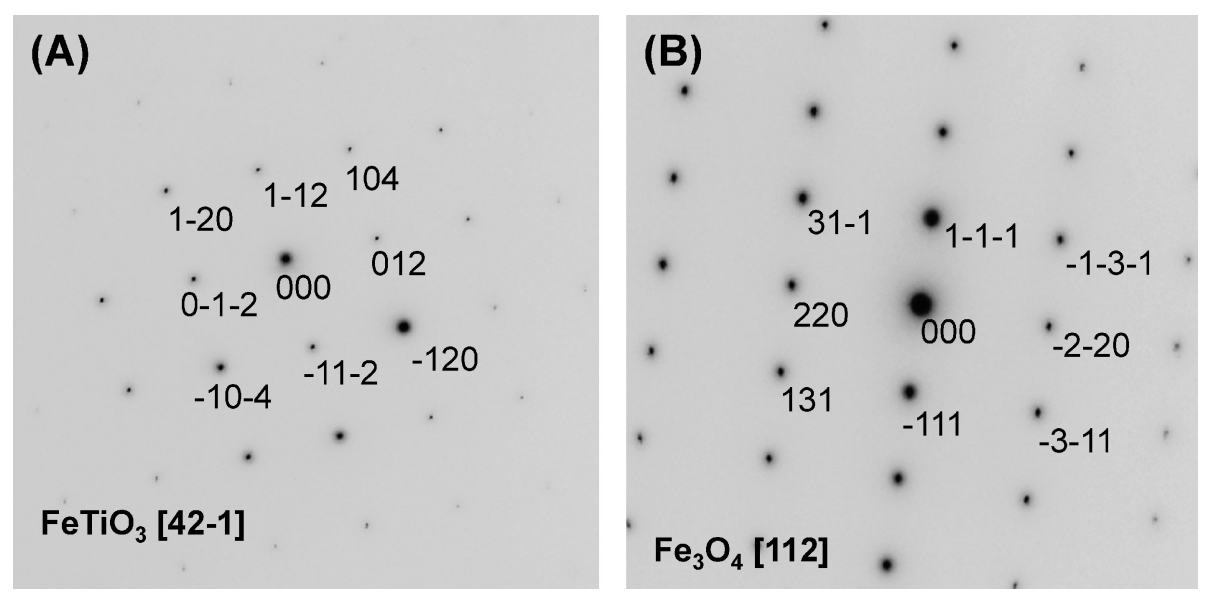

Fig. 9 Electron diffraction patterns of grains A and B shown in Fig. 7.

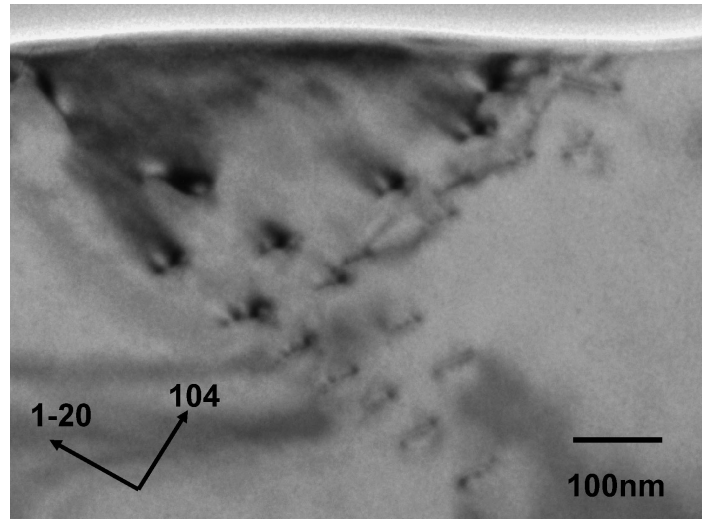

Fig. 10 Transmission electron micrograph of dislocation lines in ilmenite crystal.

位と考えられる。一般に, 表面からの転位の導入には大きな 力が必要とされ, 結晶を研磨したときの砥粒との摩擦などで 表面に高い応力が加わったときに同様な転位が導入され る10). 観察された砂鉄由来とみられるこれらの粒子の大き さは, 一般に採取される砂鉄に比較してかなり小さく, 観察 された転位は顔料として利用するときに砕いて使用した痕跡 のひとつと考えられる.

黒色粒子は辰砂粒子の中に混合されたように分布してお り, 壁画の内外からの污染物質とは考えにくく, 赤色の色調 を変えるために添加した可能性が高い. 一般に, 黒い顔料を 加えることによって色調を深くすることができる.しかし， 本試料の場合, この議論を可能にする光学測定ができるほど 試料の状態は良くなく, 絵画技法等は今後の研究に残された 課題である.

\section{4. まと め}

高松塚古墳出土の漆喰片に付着していた顔料層の黒色物質 などの観察と分析を行った. 赤色顔料中に混じっている黒色
物質は砂鉄成分と推定されるマグネタイトおよびイルメナイ トである，また，付随して Zr を含む鉱物粒子も観察され た. 前報で述べた辰砂以外の検出粒子が顔料として用いられ たものか，また混入粒子であるか，あるいは下塗りなどとし て使われたのかは, この研究の範囲では不明である. 高松塚 古墳壁画は大部分が国宝に指定を受けていることもあり, 原 則として非破壊 · 非接触法による分析が進められている. 本 研究で実験に供した試料は文化庁の古墳壁画の保存活用に関 する検討会等の倫理的な検討を経てサンプリングされたもの である. 高松塚壁画には青, 緑などの顔料が使われて抢り, 引き続き研究を進めている.

試料を提供してくださった奈良教育大学金原正明教授, 走 査型電子顕微鏡および透過型電子顕微鏡の観察に協力して戴 いた侏日立ハイテクノロジーズの坂上万理氏, 渡邊俊也氏な らびに下津輝穂氏, 電子線回折図形の解析にご協力戴いた 永田文男博士に深謝する. 本研究の研究費の一部は, 文化庁 および文部科学省科学研究費 (課題 No.22360295 および No.25289255: 代表研究者 北田正弘)によるもので, ご支援 に感謝する.

文献

1) T. Sano, Y, Hayakawa and S. Miura: Conservation Science 48 (2009) 119-131.

2) M. Kitada, Y. Kohzuma, T. Koezuka and T. Toru: J. Japan Inst. Met. Mater. 79 (2015) 64-70.

3) S. Nagakura et al. (Eds.): Rikagaku-jiten, $5^{\text {th }}$ edition, (Iwanami, Tokyo, 1998) pp. 598-599.

4) S. Nagakura et al. (Eds.): Rikagaku-jiten, $5^{\text {th }}$ edition, (Iwanami, Tokyo, 1998) p. 1168.

5) S. Nagakura et al. (Eds.): Rikagaku-jiten, $5^{\text {th }}$ edition, (Iwanami, Tokyo, 1998) pp. 91-92.

6) A. Rusakov and G. S. Zhdanov: Nauk U.S.S.R. 77(1950) 411414.

7) JCPDS No.01-075-1230.

8) JCPDS No.01-071-6336.

9) M. Kitada: Muromachi-ki-Nihontou-no-bisaikouzou, (in Japanese), (Uchidarokakuho, Tokyo, 2008) p. 36.

10) M. Kitada: J. Mater. Sci. 15 (1980) 1684-1690. 